\title{
PENGARUH KERAGAMAN BELANJA TERHADAP KETIMPANGAN PENDAPATAN ANTAR DAERAH DI PROVINSI JAMBI
}

\author{
Wiyan Mailindra ${ }^{1}$
}

\begin{abstract}
The purpose of this study was to determine income inequality and the effect diversity of expense toward income inequality in the period 2005-2015. The analysis method used quantitative analysis with Williamson Index analysis and simple regression, the date got from ten districts in jamby province. The results this study showed income inequality between regions during the period has category medium inequality, the variety of region expense has effect positive significant to income inequality level. Conclusion this study was the higher level of diversity of expense will be increase income inequality between regions. The policy implication of this research was develop the economic development center that taked to the potential of each region by utilizing resources in the region so that the level of income inequality between regions is not too high.

Keywords : diversity of expense, income inequality, economic development, potential of region.
\end{abstract}

\section{PENDAHULUAN}

Pembangunan ekonomi berorientasi meningkatkan kesejahteraan masyarakat (social's walfare), Pembangunan ekonomi merupakan suatu proses kenaikan pendapatan perkapita dalam kurun waktu tertentu. Kenaikan pendapatan perkapita identik dengan kenaikan pertumbuhan ekonomi yang di ukur dari kenaikan Produk Domestik Bruto (PDB) perkapita dan di barengi dengan usaha menekankan laju pertumbuhan penduduk, meningkatkan produksi, dan nilai tambah produk sektoral. Tolak ukur keberhasilan pembangunan dapat dilihat dari pertumbuhan ekonomi, inflasi yang rendah, dan semakin kecilnya ketimpangan antar daerah, antar penduduk, dan antar sektor.

Untuk menurunkan ketimpangan pendapatan, pemerintah mengeluarkan undang-undang No.32 tahun 2004 sebagai pengganti undang-undang No.22 tahun 1999 tentang pemerintah daerah (otonomi daerah), prinsip otonomi daerah menggunakan prinsip otonomi seluas-luasnya dalam arti daerah di beri kewenangan mengurus dan mengatur semua urusan pemerintahan daerah termasuk yang menjadi urusan pemerintahan pusat di daerah. Pemerintahan daerah memiliki kewenangan membuat kebijaksanaan daerah untuk memberi pelayanan, meningkatkan peran serta prakarsa dan pemberdayaan masyarakat yang bertujuan meningkatkan kesejahteraan masyarakat (Tan, 2010).

Ketimpangan pendapatan ditentukan oleh jenis pembangunan ekonomi yang ditunjukkan untuk ukuran Negara, dasar sumber daya alam, dan kebijakan yang dianut (Kuncoro, 2006). Dengan kata lain kebijakan dan dimensi struktural perlu diperhatikan selain laju petumbuhan ekonomi. Oleh karena itu Dalam upaya mengurangi ketimpangan maka alokasi belanja daerah harus diarahkan pada sektor-sektor yang banyak menyerap tenaga kerja, peningkatan kualitas sumberdaya manusia dan peningkatan kualitas kesehatan serta penyediaan infrastruktur berupa prasarana jalan yang kualitasnya semakin baik sehingga

${ }^{1}$ STIE Graha Karya 
mampu mendorong peningkatan dan percepatan mobilitas penduduk maupun barang, sehingga akan meningkatkan pertumbuhan ekonomi.

Secara teoritis pertumbuhan ekonomi yang meningkat akan berdampak terhadap peningkatan pendapatan perkapita masyarakat diikuti dengan penurunan jumlah angka kemiskinan, namun pada kenyataan belum terbukti kebenarannya. Pertumbuhan ekonomi tidak menjamin adanya peningkatan pendapatan perkapita serta pengurangan kemiskinan. Ini terjadi karena pemerintah pusat terkadang cenderung kurang memperhatikan masyarakat miskin atau bahkan pencapaian distribusi pendapatan dilakukan dengan mengorbankan laju pertumbuhan ekonomi (Kuncoro, 2006). Peran pemerintah dalam meningkatkan Pertumbuhan ekonomi diantaranya adalah alokasi dana APBD khususnya untuk pengeluaran yang produktif berupa belanja daerah yang digunakan dalam hal peningkatan sumber daya manusia demi untuk mencapai pemerataan kesejahteraan masyarakat.

Sebagai contoh penelitian yang dilakukan Sjafrizal (2008) pada penelitiannya yang berjudul "Pertumbuhan Ekonomi dan Ketimpangan Regional Wilayah Indonesia Bagian Barat”, menyatakan bahwa masalah pokok yang terjadi adalah : pertama Berhubungan dengan permasalahan dalam pemanfaatan SDA yang tersedia, kedua Menyangkut masalah sosial budaya yang timbul dari tingkah laku dan pola kehidupan masyarakat. Ketiga mengenai pengalokasian anggaran pembangunan.

Penelitian selanjutnya tentang "Dampak Desentralisasi Fiskal Terhadap pertumbuhan Ekonomi dan Ketimpangan Pendapatan antar Daerah di Indonesia" oleh Joko Waluyo (2007), menyimpulkan bahwa dampak desentralisasi fiskal terhadap kesenjangan pendapatan antar daerah lebih terasa di Kawasan Timur Indonesia (KTI) dibandingkan dengan Kawasan Barat Indonesia (KBI). Hal ini ditunjukkan dengan dengan pertumbuhan ekonomi yang lebih tinggi di KTI dan berada diatas rata-rata nasional. Pulau Jawa dan Bali merupakan daerah yang paling rendah pertumbuhan ekonominya dengan adanya kebijakan desentralisasi fiskal. Kesimpulan secara umum menunjukkan bahwa kebijakan desentralisasi fiskal di Indonesia belum mampu mengurangi kesenjangan pendapatan antardaerah.

Masrida Zasriati (2010) melakukan penelitian yang berjudul "Pengaruh Dana Alokasi Perimbangan Terhadap Ketimpangan Ekonomi Regional di Provinsi Jambi”. Dalam penelitiannya ditarik kesimpulan Ketimpangan pembangunan Ekonomi antar Kabupaten/Kota di Provinsi Jambi selama periode 2000-2010 mengalami peningkatan (divergence) secara rata-rata sebesar 0,40 artinya ketimpangan yang relatif sedang sesuai dengan kriteria yaitu berkisar antaar $0<\mathrm{Vw}<1$ apabila $\mathrm{Vw}$ mendekati 1 (satu) berarti sangat timpang dan bila Vw mendekati 0 (nol) berarti sangat merata.

Sedangakan menurut Rita Friyansari (2011) dalam penelitiannya yang berjudul "Analisis Kinerja Anggaran Belanja dan Hubungannya Dengan Indeks Ketimpangan Pembangunan Antar Wilayah Kabupaten/Kota Dalam Provinsi Jambi", diketahui dari hasil pengukuran model Indeks Williamson, diketahui Indeks ketimpangan pembangunan antar wilayah di Provinsi Jambi berada pada Vw 0,369 - 0, 364 dengann rata-rata sebesar 0,3722 berarti pemerataan pembangunan antar wilayah di Provinsi Jambi berada pada level mendekati merata atau ketimpangan relatif kecil akan tetapi trend ketimpangan seperti yang cenderung meningkat yang berarti ketimpangan bergeser menjauhi pemerataan. 
Menurut Hirschman dalam Arsyad (1993) daerah suatu Negara dapat dibedakan menjadi daerah kaya dan daerah miskin. Jika ketimpangan antara kedua daerah tersebut semakin menyempit berarti terjadi imbas yang baik (Trickling down effect). Sedangkan jika ketimpangan antara kedua daerah tersebut semakin jauh berarti terjadi proses pengkutuban (Polarization Effect).

Thee Kian Wie (1981) menyatakan bahwa ketimpangan distribusi pendapatan dari sudut pandangan ekonomi dibagi menjadi :

1. Ketimpangan pembagian pendapatan antar golongan penerima pendapatan (size distribution income).

2. Ketimpangan pembagian pendapatan antar daerah perkotaan dan daerah pedesaan (urban-rural income disparitie).

3. Ketimpangan pembagian pendapatan antar daerah (regional income disparities).

Todaro menyatakan bahwa ketimpangan dapat terjadi apabila pendapatan dan belanja daerah tidak seimbang.

Belanja daerah merupakan perkiraan beban pengeluaran daerah yang dialokasikan secara adil dan merata agar relative dapat dinikmati oleh seluruh kelompok masyarakat tanpa diskriminasi, khususnya dalam pemberian pelayanan umum ( Bastian, 2006). Sedangkan belanja daerah menurut Peraturan Menteri Dalam Negeri Nomor 13 Tahun 2006 Tentang Pedoman Pengurusan, Pertanggung Jawaban dan Pengawasan Keuangan Daerah Serta Tata Cara Penyusunan Anggaran Pendapatan dan Belanja Daerah Pelaksanaan Tata Usaha Keuangan Daerah dan Belanja Daerah, adalah semua pengeluaran kas daerah dalam periode tahun anggaran tertentu yang menjadi beban atau kewajiban pemerintah daerah, yang diikuti sebagai pengurang nilai kekayaan bersih.

Untuk Provinsi Jambi sendiri rata-rata realisasi belanja daerahnya selama periode tahun 2005 sampai 2015 adalah sebesar Rp 1.020.262 Juta. Jika dibandingkan dengan tahun 2005, Total belanja daerah Provinsi Jambi sangat kecil yakni sebesar Rp. 273.677 Juta, meningkat sebesar 51,68 persen ditahun 2006 yakni sebesar Rp. 415.102 juta. Hingga tahun 2014 belanja daerah Provinsi Jambi meningkat sebesar 19,17 persen dari tahun 2012 sebesar Rp 1.670.047 juta pada tahun 2013. Baru pada tahun 2014 perkembangan belanja daerah Provinsi Jambi menurun sebanyak 9,88 persen dari tahun sebelumnya menjadi Rp 1.504.935 juta. Akan tetapi kembali meningkat pada tahun 2015 sebesar 2,08 persen sebesar Rp. 1.536.271 juta. Dana belanja daerah yang meningkat selama periode tersebut diharapkan dapat menjadi salah satu faktor utama yang mendorong peningkatan pertumbuhan ekonomi. Karena jika peningkatan pertumbuhan ekonomi Provinsi Jambi dibarengi pada peningkatan belanja daerah pula, diharapkan dapat menjadi salah satu faktor penunjang peningkatan pendapatan masyarakat secara keseluruhan, sehingga Provinsi Jambi dapat mencapai pemerataan distribusi pendapatan antar daerah di Provinsi Jambi.

Dari uraian di atas penulis teratarik melakukan penelitian dengan judul

"Pengaruh Keragaman Belanja Terhadap Ketimpangan Pendapatan Antar Daerah di Provinsi Jambi".

\section{METODE PENELITIAN}

Dalam penelitian ini, penulis akanmenggunakan metode Library Research (kepustakaan) yang mana metode dalam penelitian ini nantinya menggunakan 
teori-teori yang diambil dari buku literatur dan spesifikasinya sebagai pedoman yang mendukung dan relevan dengan pembahasan

Objek penelitian adalah seluruh kabupaten/kota se provinsi jambi, dan data yang digunakan semua data yang berkaitan dengan penelitian.

Metode analisis data yang digunakan dalam penelitian ini adalah metode analisis data kuantitatif untuk menghitung besarnya keragaman belanja di Provinsi Jambi, menghitung besarnya keragaman belanja daerah di Provinsi Jambi, serta mengetahui besarnya pengaruh keragaman belanja daerah terhadap ketimpangan pendapatan yang terjadi di Provinsi Jambi.

\section{Analisis Keragaman Belanja Daerah}

\section{HASIL DAN PEMBAHASAN}

Kesenjangan belanja antar daerah di Provinsi Jambi dapat dilihat dari besarnya keragaman belanja Provinsi Jambi. menghitung besarnya keragaman belanja Provinsi Jambi dilakukan menggunakan pendekatan Standar Deviasi. Semakin besar nilai dari standar deviasi maka semakin besar jarak rata-rata setiap belanja Kabupten/Kota terhadap rata-rata belanja di Provinsi Jambi (Robby,2010).

Untuk melihat besarnya keragaman belanja di Provinsi Jambi di sajikan pada grafik berikut

\section{Graffik I. Keragaman Belanja Provinsi Jambi Periode Tahun 2005-2015}

\section{Keragaman Belanja (Juta Rp)}

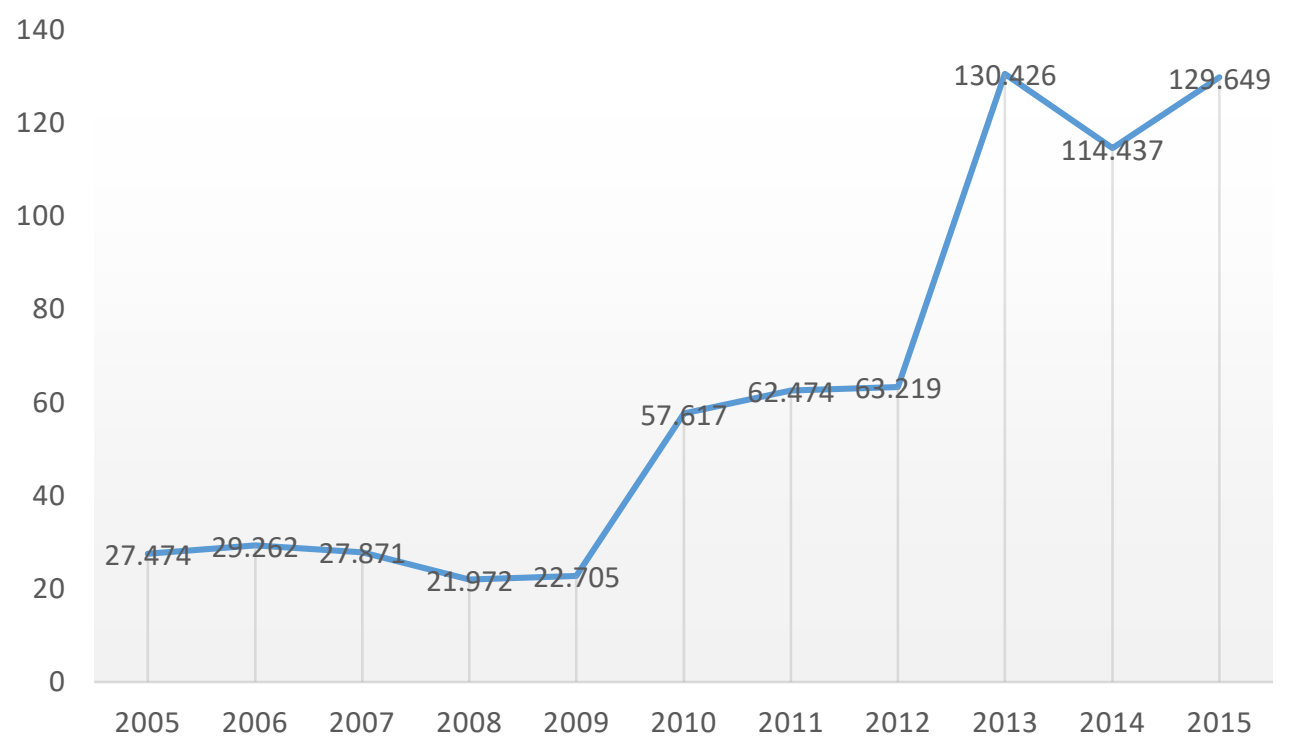

Data diolah, 2015

Dari grafik diatas diketahui bahwa angka keragaman belanja daerah Kabupaten/Kota di Provinsi Jambi ternyata berfluktuatif dan ketidakmenentuan setiap tahun. Rata-rata keragaman belanja daerah Kabupaten/Kota di Provinsi Jambi selama tahun 2005-2015 yaitu sebesar Rp. 62.464 Juta.

Pada tahun 2008 keragaman belanja daerah Provinsi Jambi sebesar Rp. 21.972 Juta, nilai keragaman terendah dibandingkan dengan rata-rata keragaman belanja Provinsi Jambi periode tahun 2005-2015. Jika dilihat pada 
tahun 2005 sampai dengan tahun 2012 keragaman belanja daerah Kabupaten/Kota di Provinsi Jambi masih menunjukkan angka yang berfluktuasi dan ketidakmenentuan, namun angka keragaman tahun-tahun tersebut masih dalam angka keragaman yang kecil.

Peningkatan angka keragaman belanja yang besar di Provinsi Jambi terjadi pada tahun 2013 sampai dengan tahun 2015. Besarnya keragaman belanja pada tahun 2013-2015 mengisyaratkan besarnya jarak rata-rata belanja daerah di Provinsi Jambi pada tahun tersebut. Keragaman belanja pada tahun 2013 meningkat tajam sebesar Rp. 130.426 juta. Angka ini merupakan nilai tertinggi keragaman belanja daerah Provinsi Jambi selama periode tahun 20052015.

Keragaman yang tinggi pada tahun 2013 dikarenakan adanya peningkatan alokasi belanja langsung yang cukup besar pada Kabupaten Tanjung Jabung Barat dan Kabupaten Tanjung Jabung Timur, diatas belanja langsung Kabupaten/Kota di Provinsi lainnya. Angka belanja langsung Kabupaten Tanjung Timur yaitu sebesar Rp 525.091 juta dan Kabupaten Tanjung Jabung Barat sebesar Rp 422.923, sedangkan ada daerah lain yang alokasi belanja langsung daerahnya kecil seperti Kabupaten Kerinci sebesar Rp 178.943 juta. Selanjutnya keragaman belanja daerah tahun 2014 sedikit menurun walaupun masih diatas rata-rata keragaman belanja tahun 2005-2015 sebesar Rp 114.437 juta. Dan meningkat kembali menjadi Rp 129.649 pada tahun 2015.

Keragaman belanja daerah yang besar ini dikarenakan pengaruh belanja daerah yang cenderung semakin meningkat pada tiap Kabupaten/Kota seiring dengan peningkatan aktifitas ekonomi seluruh Kabupaten/Kota di Provinsi Jambi. Terutama pada daerah-daerah yang dapat memanfaatkan peluang ekonominya.

Belanja daerah yang beragam pada Kabupaten/Kota berimplikasi adanya tingkat kesejahteraan masyarakat yang beragam pula. Jika instrument belanja daerah seperti belanja langsung lebih diutamakan dibanding belanja tak langsung dalam hal ini, maka pencapaian kesejahreraan masyarakat sebagai tujuan dari pembangunan ekonomi dapat dirasakan lebih nyata seiring dengan peningkatan belanja daerah yang dilakukan oleh pemerintah Kabupaten/Kota. Pengelolaan sumber keuangan yang berlangsung dalam otonomi daerah ternyata tidak secepatnya berubah menuju kesejahteraan rakyat dan makin membaiknya pelayanan publik. Khususnya infrastruktur agar semua kegiatan ekonomi dapat berjalan dengan baik.

\section{Analisis Ketimpangan Pendapatan Antar Daerah}

Untuk melihat seberapa besar pemerataan pendapatan masyarakat di Provinsi Jambi dilakukan dengan menggunakan pendekatan Indeks Williamson. Dengan menggunakan pendekatan ini dapat diketahui bagaimana perkembangan pembangunan demi mencapai suatu pemerataan yang di lakukan oleh pemerintah. Untuk mengetahui seberapa besar ketimpangan yang terjadi, variabel yang digunakan dalam mengitung indeks Williamson ini yaitu jumlah penduduk serta pendapatan perkapita masing-masing Kabupaten/Kota di Provinsi Jambi. 
Tabel 2. Indeks Williamson Provinsi Jambi tahun 2005-2015

Indeks Williamson Provinsi Jambi

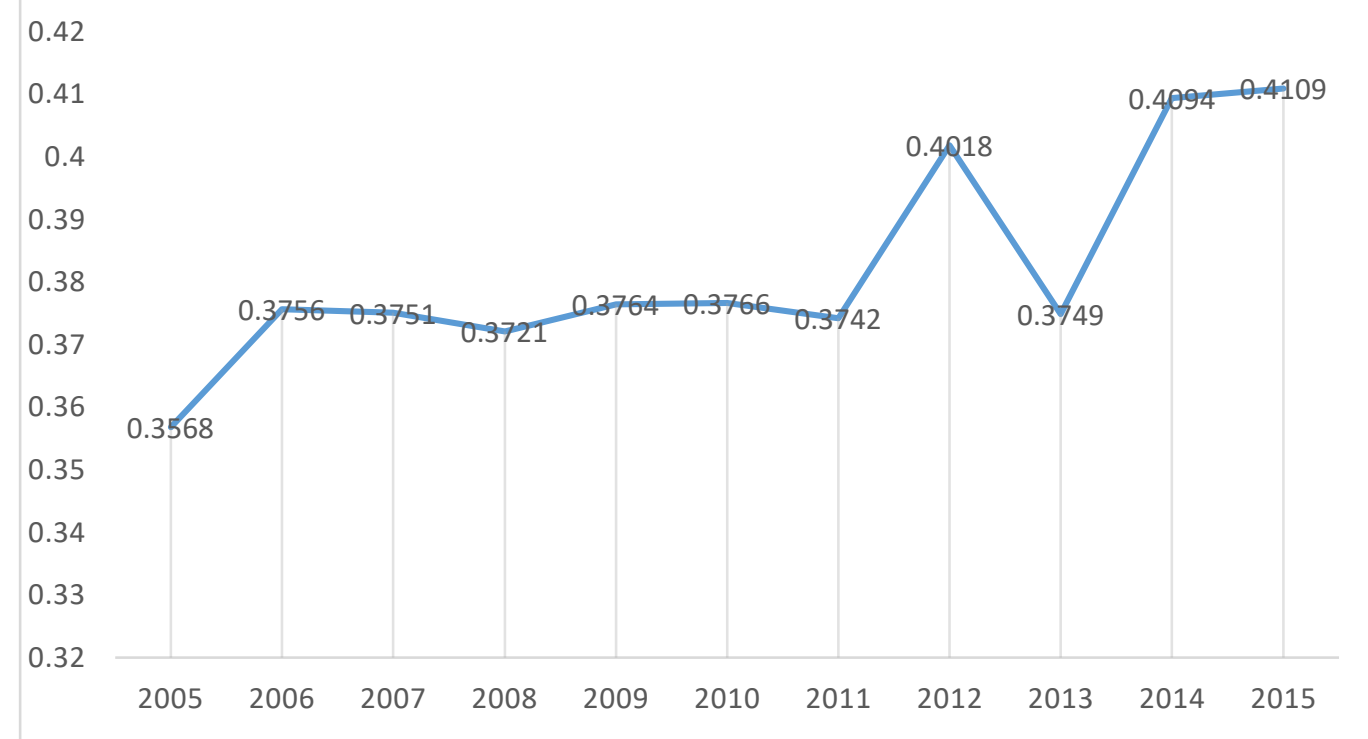

Data diolah, 2015

Dari grafik 2 terlihat bahwa nilai Indeks Williamson (Vw) Provinsi Jambi secara rata-rata selama tahun 2005-2015 sebesar 0,3821. Nilai indeks yang berada diantara 0,3-0,4. Artinya ketimpangan pendapatan antar daerah di Provinsi Jambi selama tahun tersebut termasuk kedalam ketimpangan yang tergolong sedang. Sedangkan nilai Vw terendah Provinsi Jambi terjadi pada tahun 2005 juga tergolong sedang sebesar 0,3568. Dan nilai Vw tertinggi pada tahun 2015 sebesar 0,4109 tergolong pada ketimpangan pendapatan yang tinggi.

Angka ketimpangan pendapatan yang tergolong tinggi selama tahun 2005-2015 terjadi pada tahun 2012 sebesar 0,4018, ini disebabkan nilai harga nilai tambah produk migas mencapai tingkat harga tertinggi pada tahun tersebut, sekaligus meningkatkan nilai nominal PDRB pada Kabupaten/Kota di Provinsi Jambi yang memiliki produk migas.

Selanjutnya tahun 2014 sebesar 0,4094, dan tahun 2015 sebesar 0,4109 yang merupakan nilai ketimpangan tertinggi Provinsi Jambi selama tahun 2005-2015. Tingginya nilai ketimpangan pada tahun tersebut dikarenakan adanya peningkatan pada sisi PDRB yang merupakan variabel penentu besarnya pendapatan perkapita sebagai faktor utama penentu ketimpangan pendapatan yang terjadi.

Selain itu adanya peningkatan aktifitas ekonomi oleh setiap daerah, maka kesempatan dan peluang pembangunan yang ada umumnya dimanfaatkan oleh daerah-daerah yang kondisi pembangunan sudah lebih baik. Sedangkan daerah yang masih sangat terbelakang tidak mampu memanfaatkan peluang ini karena keterbatasan prasarana dan sarana serta rendahnya kualitas sumberdaya manusia. Hambatan ini mengakibatkan ketimpangan pendapatan antar daerah cenderung lebih cepat di daerah dengan kondisinya lebih baik, sedangkan daerah yang terbelakang tidak banyak mengalami kemajuan. 
Secara umum, penyebab terjadinya ketimpangan pendapatan antar daerah di Provinsi Jambi ini yaitu faktor kepemilikan sumber daya alam dan faktor persebaran penduduk. Beberapa Kabupaten/Kota seperti Kabupaten Tanjung Jabung Timur, Tanjung Jabung Barat, Muaro Jambi, Batanghari, Sarolangun, dan Tebo memiliki sumber minyak dan gas alam sementara Kabupaten/Kota lainnya tidak memiliki sumber migas. Seperti diketahui produksi migas agak sulit diprediksi begitu juga dengan harganya. Harga migas yang tinggi akan berdampak meningkatnya nilai PDRB pada daerah-daerah yang memiliki potensi sumber migas. Peningkatan PDRB akan diikuti dengan peningkatan pendapatan perkapita pada daerah berpotensi, sedangkan daerah yang tidak memiliki potensi migas pendapatannya cenderung rendah dibanding daerah berpotensi.

3. Pengaruh Keragaman Belanja Terhadap Ketimpangan Pendapatan Antar Daerah

Tabel 3. Rekapitulasi Hasil Regresi Model

\begin{tabular}{lrrrr}
\hline \multicolumn{1}{c}{ Variabel } & Koefisien & \multicolumn{2}{c}{ t hitung } & Sig. T \\
\hline Konstanta & 0,366 & 48,041 & 0,000 \\
Keragaman Belanja & $2,591 \mathrm{E}-7$ & \multicolumn{2}{c}{2,544} & 0,031 \\
\hline $\mathrm{R} \quad=0,647$ & & F hitung & $=6,473$ & \\
$\mathrm{R}^{2} \quad=0,418$ & & Sig. F hitung $=0,031$ & \\
$\mathrm{t}$ tabel $=1,812$ & & F tabel & $=4,96$ &
\end{tabular}

Data diolah

Rekapitulasi hasil regresi model di atas dapat ditulis dalam bentuk persamaan sebagai berikut:

$\mathrm{Y}=0,366+2,591 \mathrm{E}-7 \mathrm{~K}$

Seperti telah dikemukakan pada bagian metode analisis data bahwa untuk mengetahui pengaruh keragaman belanja daerah terhadap ketimpangan pendapatan di Provinsi Jambi dilakukan dengan menggunakan model persamaan regresi sederhana.

Pengolahan data dilakukan dengan menggunakan bantuan program komputer SPSS versi 16.0 berdasarkan data-data yang diperoleh sebanyak 11 tahun data penelitian. Ketimpangan pendapatan sebagai variabel dependent yang dalam hal ini dilambangkan dengan $\mathrm{Y}$, sedangkan keragaman belanja sebagai variabel independent dilambangkan dengan $\mathrm{X}$

\section{Pengujian Hipotesis}

\section{a. Pengujian Secara Simultan}

(Uji F Statistik)

Uji F statistik dilakukan untuk melihat pengaruh variabel independent terhadap variabel dependent secara bersama-sama. Hasil pengujian menunjukkan bahwa nilai $\mathrm{F}$ statistik sebesar 6,473 dimana $\mathrm{F}$ tabel sebesar 4,96. Dengan demikian nilai F statistik $(6,473)>\mathrm{F}$ tabel $(4,96)$ pada tingkat keyakinan 5 persen $(\alpha=5 \%)$. Artinya $\mathrm{H}_{\mathrm{a}}$ diterima dan $\mathrm{H}_{0}$ ditolak Maka dapat disimpulkan bahwa secara bersama-sama keragaman belanja daerah berpengaruh signifikan terhadap tingkat ketimpangan pendapatan di Provinsi Jambi. 


\section{b. Pengujian Secara Parsial (Uji t Statistik)}

Untuk melihat hasil tingkat keberartian setiap variabel independent terhadap variabel dependent secara parsial (terpisah) dapat diuji dengan pengujian $\mathrm{t}$ statistik. Pada variabel keragaman belanja, nilai t-hitung di peroleh sebesar 2,544 pada $\alpha$ sebesar 5\% persen dan t-tabel sebesar 1,812 yang berarti t-hitung > t-tabel. Maka secara parsial variabel keragaman belanja berpengaruh signifikan terhadap tingkat ketimpangan pendapatan di Provinsi Jambi. Nilai yang positif pada t-hitung menunjukkan bahwa kenaikan variabel keragaman belanja akan menaikkan tingkat ketimpangan pendapatan.

Signifikannya pengaruh variabel keragaman belanja daerah terhadap ketimpangan pendapatan antar derah di Provinsi Jambi selama tahun 20052015 karena dengan adanya perbedaan alokasi belanja daerah antar Kabupaten/Kota tersebut menyebabkan adanya perbedaan dalam penyediaan infrastruktur baik fisik maupun sosial antar Kabupaten/Kota. Hal ini pada gilirannya akan menjadikan perbedaan dalam aktifitas dan mobilitas kegiatan ekonomi, yang pada akhirnya menyebabkan terjadi ketimpangan pendapatan antar daerah.

Sedangkan pada sisi pengalokasian belanja daerah yang tinggi pada kenyataanya lebih besar digunakan untuk keperluan belanja tidak langsung. Antara lain digunakan untuk keperluan belanja pegawai berupa gaji dan tunjangan, imbasnya alokasi untuk pelayanan masyarakat menjadi sangat minim. Belanja pegawai yang besar harus ditekan, agar dapat digunakan untuk belanja yang lain. Komponen belanja daerah yang harus diprioritaskan adalah belanja modal yang dapat digunakan untuk membiayai infrastruktur, pusat maupun daerah, agar dapat mendorong peningkatan aktifitas ekonomi daerah sehingga ketimpangan pendapatan antar daerah dapat dikurangi karena mobilitas barang dan jasa, khususnya investasi berajalan dengan lancar.

\section{c. Analisis Regresi}

\section{1) Koefisien Determinasi}

Besarnya pengaruh variabel independen (keragaman belanja) terhadap variabel dependen (ketimpangan pendapatan) dapat ditunjukkan dengan nilai koefisien determinasi. Besar koefisien determinasi ditunjukkan dengan nilai $\mathrm{R}$ square pada model regresi. Nilai $\mathrm{R}$ square dalam model regresi ini diperoleh sebesar 0,418 . Hal ini berarti besarnya kemampuan variabel keragaman belanja daerah menjelaskan variasi (naik dan turunnya) variabel ketimpangan pendapatan adalah sebesar 41,8 persen, sedangkan sisanya sebesar 58,2 persen dijelaskan oleh variabel lain yang tidak dimasukkan ke dalam persamaan regresi ini. Kecilnya nilai $\mathrm{R}$ square yang diperoleh dalam analisis ini dimungkinkan dikarenakan penelitian hanya menggunakan satu variable independen

\section{2) Koefisien Regresi}

Nilai koefisien regresi dari variabel keragaman belanja yaitu sebesar 2,591E-7 Angka ini menunjukkan besarnya pengaruh perubahan variabel keragaman belanja terhadap variabel ketimpangan pendapatan $\left(\mathrm{V}_{W}\right)$. Bila variabel keragaman belanja meningkat sebesar Rp. 1 Juta, maka indeks ketimpangan pendapatan $\left(\mathrm{V}_{W}\right)$ akan meningkat sebesar 
2,591E-7. Begitu pula sebaliknya, bila variable belanja menurun sebesar Rp. 1 juta, maka indeks ketimpangan pendapatan $\left(\mathrm{V}_{W}\right)$ akan menurun sebesar 2,591E-7. Nilai konstanta adalah sebesar 0,366 artinya jika nilai keragaman belanja sebesar Rp. 0, maka indeks ketimpangan pendapatan $\left(\mathrm{V}_{W}\right)$ adalah sebesar 0,366 .

\section{Simpulan}

\section{SIMPULAN DAN SARAN}

Berdasarkan hasil penelitian dan pembahasan, maka dapat ditarik kesimpulan sebagai berikut:

1. Selama tahun 2005-2015 keragaman belanja daerah di Provinsi Jambi rata-rata menunjukkan peningkatan belanja daerah. Rata-rata nilai Standar Deviasi Provinsi Jambi selama tahun 2005-2015 adalah Rp. 62.464 Juta. Artinya besar jarak rata-rata setiap belanja Kabupaten/Kota terhadap rata-rata belanja di Provinsi Jambi adalah sebesar Rp 62.464 Juta. Keragaman terbesar pada tahun 2014 sebesar Rp 130.426, hal ini dikarenakan adanya peningkatan alokasi belanja langsung yang cukup besar pada Kabupaten Tanjung Jabung Barat dan Kabupaten Tanjung Jabung Timur diatas belanja langsung Kabupaten/Kota di Provinsi lainnya.

2. Selama tahun 2005-2015 tingkat ketimpangan pendapatan antar Kabupaen/Kota di Provinsi Jambi selalu meningkat dengan tingkat ketimpangan yang tergolong sedang $\left(V_{w} \quad 0,3-0,4\right)$ rata-rata sebesar 0,3821. Ketimpangan pendapatan tertinggi pada tahun 2015 sebesar 0,4109.

3. Secara simultan dan parsial keragaman belanja daerah berpengaruh signifikan terhadap ketimpangan pendapatan $\left(\mathrm{V}_{W}\right)$ antar daerah di Provinsi Jambi selama tahun 2005-2015.

\section{Saran}

Berdasarkan kesimpulan diatas, maka dapat diberikan saran sebagai berikut :

1. Dengan tingkat keragaman belanja daerah semakin meningkat, maka pemerintah perlu memperhatikan alokasi belanja daerah. Alokasi belanja yang semakin meningkat perlu diikuti juga dengan peningkatan kegiatan perekonomian diseluruh daerah Kabupaten/Kota di Provinsi Jambi.

2. Ketimpangan pendapatan yang semakin meningkat perlu dikurangi oleh pemerintah dengan mengembangkan pusat pengembangan ekonomi yang memperhatikan potensi dari masing-masing wilayah dengan memanfaatkan sumberdaya di wilayah tersebut sehingga tingkat ketimpangan pendapatan antar daerah tidak terlalu tinggi.

3. Mengingat peningkatan keragaman belanja daerah mempengaruhi ketimpangan pendapatan, penganggaran komponen belanja daerah harus diperhatikan. Alokasi belanja langsung daerah tidak boleh lebih besar dari belanja tak langsung. Belanja langsung yang dimaksud dipergunakan kepada penyediaan sarana seperti infrastruktur, sarana kesehatan, dan sarana pendidikan. Bila hal ini dilakukan salah satunya dengan peningkatan sarana infrastruktur, maka ketimpangan pendapatan melalui komponen belanja dapat dikurangi. Hal ini dikarenakan kegiatan perdagangan khususnya investasi dapat diperlancar pada daerah kurang maju. Sehingga kegiatan produksi dan penyediaan lapangan kerja akan meningkat, seiring dengan meningkatnya pendapatan khususnya pada daerah yang kurang maju. 
DAFTAR PUSTAKA

Adisasmita, H. Rahardjo. 2005. Dasar-dasar Ekonmi Wilayah. Yogyakarta: Graha Ilmu.

Anonim, 2002. Jurnal Penelitian Universitas Jambi. Jambi: Lembaga Penelitian Universitas Jambi.

Anonim, 2012. Beberapa Tahun Terbitan Jambi Dalam Angka. Jambi: BPS Provinsi Jambi.

Anonim. 2012. Berita Resmi Statistik Provinsi Jambi dalam http://jambi.bps.go.id/ akses tanggal 12 Mei 2013.

Anonim. 2012. Statistik Keuangan Pemerintah Kabupaten/Kota 2010-2011. Jambi: BPS Provinsi Jambi.

Anonim. 2013. Teori Pengeluaran Pemerintah dalam http://catarts.wordpress.com. Diakses Tanggal 12 Mei 2013

Arsyad, Lincolin. 1993. Pengantar Perencanaan Ekonomi, Yogyakarta: Media Widya Mandala.

Auliani, Yuli. 2010. Analisis Disparitas Pendapatan Antar Kabupaten Pemekaran dalam Wilayah Provinsi Jambi. Jambi: Skripsi FE UNJA.

Bastian, Indra. 2006. Sistem Perencanaann dan Penganggaran Pemerintahan Daerah di Indonesia. Jakarta: Salemba Empat.

Eroy, A.R.E. Ketimpangan Pembangunan dan Kemiskinan dalam http://achmadaryarozi.wordpress.com. Diakses tanggal 15 Oktober 2011.

Hidayat, wendi. 2009. Analisis Pengeluaran Pemerintah Terhadap Pertumbuhan Ekonomi Kota Jambi Sebelum dan Sesudah Otonomi Daerah. Jambi : Skripsi FE UNJA.

Kunarjo. 2002. Perencanaan dan Pengendalian Program Pembangunan. Jakarta: UI-PRESS.

Kuncoro, Mudrajad. 2004, Otonomi dan Pembangunan Daerah, Jakarta: Erlangga.

Kuncoro, Mudrajad. 2006. Ekonomika Pembangunan (Teori, Masalah, dan Kebijakan), Yogyakarta: UPP-STIM YKPN d/h YKP.

Lazio, Sonny. Pengertian dan Sumber-Sumber Pendapatan dalam http://Sonnylazio.blogspot.com. Di akses tanggal 02 April 2014.

Mangkusubroto, Guritno. 1995. Ekonomi Publik, Edisi Ketiga, Yogyakarta: Lembaga penerbit FE UGM.

Priyarsono,. \& Sahara. Modul Ekonomi Regional.

Putri, Risti. 2011. Dampak Investasi Terhadap Kettimpangan Pembanngunan Antar Wilayah Di Provinsi Jambi. Jambi : skripsi FE unja

Richardson, H.W. 2001. Dasar-Dasar Ilmu Ekonomi. Edisi Revisi. Jakarta: Lembaga Penerbit FE-UI.

Robby. Standar Deviasi dalam http://robby01343.wordpress.com. Diakses tanggal 28 April 2014

Sjafrizal, 2008. Ekonomi Regional Teori dan Aplikasi. Sumatera Barat: Baduose Media.

Sukirno, Sadono. 1994. Pengantar Teori Makro Ekonomi. Edisi kedua. Jakarta: PT. Raja Grafindo Persada.

Tan, Syamsurijal. 2010. Perencanaan Pembangunan. Jambi: Lembaga penerbit FE-UNJA

Tarigan, Robinson. 2003. Perencanaan Pembangunan Wilayah. Jakarta: Bumi Aksara.

Pengaruh Keragaman Belanja terhadap Ketimpangan Pendapatan Antar Daerah di Provinsi Jambi 
Tarigan, Robinson. 2005. Ekonomi Regional Teori dan Aplikasi. Edisi Revisi. Jakarta: PT Bumi Aksara.

Todaro, M.P. 2000. Pembangunan Ekonomi Dunia Ke Tiga. Edisi Ketujuh. Jakarta: Erlangga.

Todaro, M.P., \& Stephen C. Smith. 2004. Pembangunan Ekonomi Dunia Ke Tiga. Edisi kedelapan. Jakarta: Erlangga. 